\title{
MAGI-2 Is Critical for the Formation and Maintenance of the Glomerular Filtration Barrier in Mouse Kidney
}

\author{
Kan-Ichiro Ihara, ${ }^{*}$ Katsuhiko Asanuma, ${ }^{\dagger \ddagger}$ Tomokazu Fukuda, ${ }^{\S}$ Shyuichi Ohwada, ${ }^{\varpi}$ Midori Yoshida, and Katsuhiko Nishimori*
}

\begin{abstract}
From the Laboratory of Molecular Biology,* Department of Molecular and Cell Biology, the Laboratory of Animal Breeding and Genetics, ${ }^{\S}$ Department of Animal Biology, and the Laboratory of Functional Morphology, ${ }^{\top}$ Department of Animal Biology, Graduate School of Agricultural Science, Tohoku University, Sendai; the Division of Nephrology, ${ }^{\dagger}$ Department of Internal Medicine, Juntendo University School of Medicine, Tokyo; the Laboratory for Kidney Research, Medical Innovation Center, Graduate School of Medicine, Kyoto University, Kyoto; and the Division of Pathology," National Institute of Health Sciences, Tokyo, Japan
\end{abstract}

\author{
Accepted for publication \\ June 26, 2014. \\ Address correspondence to \\ Katsuhiko Nishimori, Ph.D., \\ Laboratory of Molecular \\ Biology, Graduate School of \\ Agricultural Science, Tohoku \\ University, Tsutsumidori- \\ Amamiyamachi 1-1, Sendai, \\ Miyagi 981-8555, Japan. \\ E-mail: knishimori@m.tohoku. \\ ac.jp.
}

\begin{abstract}
Membrane-associated guanylate kinase inverted 2 (MAGI-2) is a tight junction protein in epithelial tissues. We previously reported the detailed expression patterns of MAGI-2 in mouse tissues, including kidney podocytes, based on results obtained from Venus knock-in mice for Magi2 locus. In the present study, homozygous deletion of the Magi2 gene in mice caused neonatal lethality, which was explained by podocyte morphological abnormalities and anuria. Immunohistological analysis showed that loss of MAGI-2 function induced a significant decrease in nephrin and dendrin at the slit diaphragm of the kidney, although other components of the slit diaphragm were unchanged. Furthermore, nuclear translocation of dendrin was observed in the podocytes of the MAGI-2-null mutants, along with enhanced expression of cathepsin L, which is reported to be critical for rearrangement of the actin cytoskeleton in podocytes. Expression analysis of the null mutants showed that loss of MAGI-2 function induces abnormal expression of various types of adhesion-related molecules. The present study is the first to demonstrate that MAGI-2 has a critical role in maintaining the functional structure of the slit diaphragm and that this molecule has an essential role in the functioning of the kidney filtration barrier. (Am J Pathol 2014, 184: 2699-2708; http://dx.doi.org/10.1016/j.ajpath.2014.06.019)
\end{abstract}

Membrane-associated guanylate kinase inverted 2 (MAGI-2) is a multi-domain scaffolding protein containing multiple PDZ and WW domains. Although their function is not fully understood, these domains work as key components in the binding to proline-rich and arginine-rich proteins. In vivo, the MAGI-2 molecule is expected to have an important function in neuronal tissues, such as brain, where it is highly expressed. Consistently, MAGI-2 [alias synaptic-scaffolding molecule (S-SCAM)] has been found to localize to the postsynaptic density area of the spine. ${ }^{1}$ Furthermore, MAGI2 has been reported to bind to $N$-methyl-D-aspartate receptor (a glutamate receptor) and is localized to both excitatory and inhibitory synapses, ${ }^{2}$ both observations supporting a putative neuronal role for MAGI-2.

The knockout mouse is a powerful tool for elucidating molecular function in vivo. Mice lacking MAGI-2 exhibit abnormal elongation of dendritic spines, suggesting that this protein has an important role during morphogenesis of neurons. ${ }^{3}$ However, particular attention needs to be given to
Magi2 gene expression, because the protein molecule has three splicing variants: MAGI-2 $\alpha$, MAGI- $2 \beta$, and MAGI$2 \gamma \cdot{ }^{4}$ Knockout mice lacking MAGI-2 exhibit loss of function of only the $\alpha$ variant; the other two splicing forms remain intact. Thus, the functions mediated by the other splicing variants of MAGI-2 remain unknown.

To understand the in vivo functions of MAGI-2, we previously studied a mutant mouse having a Venus fluorescence reporter cassette inserted in exon 6 at the Magi2 locus (Venus knock-in mouse for Magi2) via the homologous recombination technique. Because exon 6 of Magi2 is common to all three variants of the protein, we can use Venus fluorescence to visualize expression of all three splicing variants of MAGI-2. Venus is a mutant form of the

Supported in part by Ministry of Education, Culture, Sports, Science and Technology of Japan Grants-in-Aid for Scientific Research 20380058 and 23380055 (K.N.) and 23591201 (K.A.).

Disclosures: None declared. 
enhanced yellow fluorescent protein, with a 30 -fold greater intensity than the original form. ${ }^{5}$ Because of this increased fluorescence of Venus, we were able to detect the detailed tissue distribution of MAGI-2. ${ }^{6}$ In brief, strong MAGI-2 expression was observed in the brain, with moderate expression in the testis and kidney. Given that exon 6 is common to all three splicing variants, insertion of the Venus reporter cassette into exon 6 is expected to cause loss of function of all forms of MAGI-2 protein. With this idea in mind, we generated homozygous crosses with the Venus knock-in mouse. We observed interesting phenotypes indicative of unknown in vivo functions of MAGI-2 protein.

\section{Materials and Methods}

\section{Generation of Magi2 $^{-/-}$Mice}

Construction of the targeting vector and generation of Magi2 (http://www.ncbi.nlm.nih.gov; GenBank accession number NM_001170746) knockout mice were performed as described previously. ${ }^{7}$ All animal studies were conducted with the authorization of the Institutional Animal Care and Use Committee of Tohoku University.

\section{Primers}

The primers used for Magi2 genotyping were forward (F1) 5'-AATAAAAATAGCTGCTTTGAGGACAGGGAG-3', reverse (R1) 5'-GTCAAATAGAACCCACAGGGATGACAAAGA-3', and reverse (R3) 5'-ATAGACGTTGTGGCTGTTGTAGTTGTACTC- $3^{\prime}$. The primers used for Magi2 RT-PCR and quantitative real-time PCR were forward 5'-ACAAAGCCTGAGGAGAACGA- ${ }^{\prime}$ and reverse 5'-CCAGCCATATGGAAGCTCAT- ${ }^{\prime}$. Other primers were as follows: Rplp0 (alias Arbp) (http://www.ncbi.nlm.nih.gov; GenBank accession number NM_007475) forward 5'TGTGTGTCTGCAGATCGGGTAC- $3^{\prime}$ and reverse $5^{\prime}$-CTTTGGCGGGATTAGTCGAAG-3'; Nphs I (http://www.ncbi. nlm.nih.gov; GenBank accession no. NM_019459) forward $5^{\prime}$-GCCACCACCTTCACACTGAC- $3^{\prime}$ and reverse $5^{\prime}$-AGACCACCAACCGCAAAGAG- $3^{\prime 8}$; and Ctsl (http://www. ncbi.nlm.nih.gov; GenBank accession no. NM_009984) forward $5^{\prime}$-GTGGACTGTTCTCACGCTCA-3' and reverse 5'-TATCCACGAACCCTGTGTCA-3'. ${ }^{\prime}$

\section{Antibodies}

The following primary antibodies were used for immunohistochemistry or immunoelectron microscopy: rat antiMAGI-2 antibody (dilution 1:100; antibody raised as the product between PDZ2 and PDZ3), guinea pig anti-nephrin antibody (1:100; GP-N2; Progen Pharmaceuticals, Darra, Australia), rabbit anti-nephrin antibody [1:1000; provided by Dr. Kan Katayama (Karolinska Institute, Stockholm, Sweden)], rabbit anti-dendrin antibody (1:50; provided by K.A. $){ }^{10}$ rabbit anti-WT-1 antibody (1:25; sc-192; Santa
Cruz Biotechnology, Dallas, TX), mouse anti-cathepsin L monoclonal antibody (1:50; ab6314; Abcam, Cambridge, UK), mouse anti-synaptopodin monoclonal antibody (1:10; G1D4; Progen Pharmaceuticals), rabbit anti-podocin antibody (1:300; provided by K.A.), ${ }^{10}$ rabbit anti-CD2AP antibody [1:300; provided by Dr. Andrey Shaw (Washington University School of Medicine, St. Louis, MO)], rat antipodocalyxin antibody (1:50; KR064; TransGenic, Kumamoto, Japan), rabbit anti-ZO-1 antibody (1:100; 40-2200; Life Technologies, Carlsbad, CA), mouse anti- $\beta$ catenin monoclonal antibody (1:100; BD Transduction Laboratories 610154; BD Biosciences, San Jose, CA), rabbit anticlaudin-5 antibody (1:100; ab53765; Abcam), and rabbit anti-claudin-1 antibody (1:200; ab15098; Abcam). The following secondary antibodies were used for immunohistochemistry or immunoelectron microscopy: Alexa Fluor 488-, 555-, or 594-conjugated secondary antibodies (1:300 to 1:500; Life Technologies), $5 \mathrm{~nm}$ gold-conjugated goat anti-guinea pig IgG (1:100; EM.GAG5; BBI Solutions, Cardiff, UK), and $5 \mathrm{~nm}$ gold-conjugated anti-rabbit IgG (1:100; EM.GAR5; BBI Solutions).

\section{Genotyping}

A 5-mm section cut from the tip of the mouse tail was digested in lysis buffer $[50 \mathrm{mmol} / \mathrm{L}$ Tris $-\mathrm{HCl}(\mathrm{pH} 7.5), 50$ $\mathrm{mmol} / \mathrm{L}$ EDTA (pH 8.0), $100 \mathrm{mmol} / \mathrm{L} \mathrm{NaCl}, 5 \mathrm{mmol} / \mathrm{L}$ dithiothreitol, $0.5 \mathrm{mmol} / \mathrm{L}$ spermidine, $1 \%$ SDS with $0.2 \mathrm{mg} /$ $\mathrm{mL}$ proteinase $\mathrm{K}$ ] overnight at $58^{\circ} \mathrm{C}$. After lysis, solubilized DNA was concentrated by isopropanol precipitation, rinsed with $70 \%$ ethanol, dried, and re-extracted with Tris-EDTA buffer. For Southern blot analysis, $3 \mu \mathrm{g}$ of genomic DNA extracted from the tail was digested with HindIII endonuclease and loaded onto $1 \%$ agarose gels. These DNA samples were subjected to electrophoresis and then were transferred to Biodyne B nylon transfer membranes (Pall, Port Washington, $\mathrm{NY}$ ). The membranes were hybridized to a ${ }^{32} \mathrm{P}$-labeled probe. The $3^{\prime}$-probe was obtained by digestion with an endonuclease and was labeled with an Amersham Megaprime DNA labeling system (GE Healthcare, Little Chalfont, UK) with $\left[{ }^{32} \mathrm{P}\right]-\mathrm{dCTP}$. For PCR analysis, TaKaRa Taq polymerase (Takara Bio, Otsu, Japan) and primers as described above were used. The wild-type allele yields a PCR amplicon of 550 bp with primers $\mathrm{F} 1$ and $\mathrm{R} 1$; primers $\mathrm{F} 1$ and $\mathrm{R} 3$ generate a 730-bp product from the knockout allele.

\section{Detection of Transcription Product}

For Northern blot analysis, Magi2 probes spanned from 2273 to 3490 nucleotides (1218 bp) in the mouse Magi2 mRNA. mRNA preparation and Northern blot analyses were performed as described previously. ${ }^{6}$ For RT-PCR, cDNA synthesis was performed with SuperScript III Reverse Transcriptase according to the manufacturer's protocol (Life Technologies). cDNA synthesis for quantitative real-time RT-PCR was performed using PrimeScript RT master mix 
(Takara Bio) according to the manufacturer's protocol. Real-time PCR was performed using SYBR Premix Ex Taq II (Takara Bio) and specific primers for Nphsl and Ctsl in the a Dice real-time thermal cycler system (Takara Bio). Normalization across samples was to the average expression of the constitutive Arbp gene.

\section{Measurement of Plasma Creatinine}

Plasma creatinine levels were measured using a drychemistry autoanalyzer (DRI-CHEM 3500V; Fuji Film, Tokyo, Japan). Breathing neonatal mice were decapitated and approximately $20 \mu \mathrm{L}$ of blood was immediately collected with a Pipeteman pipette (Gilson, Madison, WI). The blood sample was centrifuged $(700 \times g)$ for 5 minutes at room temperature to prepare plasma supernatant. A $10-\mu \mathrm{L}$ plasma sample was further processed with the autoanalyzer according to the manufacturer's protocol.

\section{Scanning Electron Microscopy}

Kidney samples (approximately $2 \mathrm{~mm}^{3}$ ) were immersed in $2.5 \%$ glutaraldehyde in $0.1 \mathrm{~mol} / \mathrm{L}$ phosphate buffer $(\mathrm{pH} 7.4)$ for 2 hours. Next, the samples were postfixed in $2 \% \mathrm{OsO}_{4}$ in $0.1 \mathrm{~mol} / \mathrm{L}$ phosphate buffer for 2 hours and then stained with $1 \%$ tannic acid in $0.1 \mathrm{~mol} / \mathrm{L}$ phosphate buffer for 1 hour at room temperature. Tissues were dehydrated in ethanol and freeze-dried with tert-butyl alcohol in a freeze dryer (ES-2030; Hitachi, Tokyo, Japan). After drying, samples were coated with platinum and palladium and were visualized with a scanning electron microscope (S-4200; Hitachi) at an accelerating voltage of $15 \mathrm{kV}$.

\section{Transmission Electron Microscopy}

Samples for transmission electron microscopy were prepared as for scanning electron microscopy, up to the staining with tannic acid. After dehydration in ethanol, samples were embedded in epoxy resin (TAAB Laboratories, Reading, England). Ultrathin sections (approximately 80 $\mathrm{nm}$ ) were cut with an ultramicrotome (Reihert-Nissei Ultracut S; Leica, Vienna, Austria) and mounted on a copper grid. The sections were stained in uranyl acetate for 1 hour and in lead citrate for 7 minutes at room temperature. Grids were viewed with a transmission electron microscope (H-7650; Hitachi) at an accelerating voltage of $100 \mathrm{kV}$.

\section{Immunohistochemistry}

The kidneys were removed, cut, and fixed in $4 \%$ paraformaldehyde in $0.1 \mathrm{~mol} / \mathrm{L}$ phosphate-buffered saline (PBS) on ice for 15 minutes and incubated in $20 \%$ sucrose in 0.1 $\mathrm{mol} / \mathrm{L}$ PBS until the tissues sank to the bottom of tube on ice. The tissues were embedded in optimal cutting temperature compound (Sakura Finetek Japan, Tokyo, Japan), snap-frozen in liquid nitrogen, and sectioned ( $5 \mu \mathrm{m}$ thick) in a cryostat. Tissue sections were mounted on MAS-coated glass slides (Matsunami, Tokyo, Japan) and blocked with blocking solution ( $2 \%$ fetal calf serum, $2 \%$ bovine serum albumin, $0.2 \%$ fish gelatin in $0.1 \mathrm{~mol} / \mathrm{L}$ PBS) for 30 minutes at room temperature. Primary antibodies diluted in blocking solution were added for 1 hour at room temperature and visualized using secondary antibodies diluted in blocking solution for 1 hour at room temperature. Sections were stained with DAPI to counterstain the nuclei, sealed with Vectashield mounting medium (Vector Laboratories, Burlingame, CA), covered, and imaged using a confocal laser scanning microscope (Olympus, Tokyo, Japan).

\section{Histological Analysis}

Kidneys were removed, cut, and fixed in $4 \%$ paraformaldehyde in $0.1 \mathrm{~mol} / \mathrm{L}$ PBS on ice overnight. After dehydration, the kidneys were embedded in paraffin. Paraffin blocks were sectioned at $5-\mu \mathrm{m}$ or $2-\mu \mathrm{m}$ thickness, and stained with hematoxylin and eosin or with periodic acid-Schiff for histological evaluation by light microscopy, respectively.

\section{Immunoelectron Microscopy}

Kidney samples (approximately $2 \mathrm{~mm}^{3}$ ) were immersed in $4 \%$ paraformaldehyde in $30 \mathrm{mmol} / \mathrm{L}$ HEPES buffer $(\mathrm{pH} 7.4)$ for 2 hours on ice. After fixation, the tissues were dehydrated in ethanol and embedded in LR White resin (London Resin, Reading, UK). Ultrathin sections (approximately 100 $\mathrm{nm})$ were cut with an ultramicrotome and mounted on a nickel grid. Immunostaining methods were as described above. After staining, grids were blocked in $1 \%$ bovine serum albumin in PBS and then postfixed in 2\% glutaraldehyde in $0.1 \mathrm{~mol} / \mathrm{L}$ PBS. Electron microscopy staining was performed with platinum blue solution (TI-Blue staining kit; Nisshin EM, Tokyo, Japan). ${ }^{11}$ Grids were viewed with a transmission electron microscope (H-7650; Hitachi).

\section{Results}

\section{Generation of Magi2 $^{-/-}$Mice}

We generated Magi2 knockout mice (Magi2 ${ }^{-1-}$ mice) in which exon 6 (encoding the first WW domain) was replaced by the Venus fluorescent protein via Cre-mediated recombination (Figure 1A). Because of the replacement of exon 6 , the mutant protein is expected to lose all of the WW domain and most of the PDZ domain. The genomic structure of the disrupted allele of the Magi2 gene locus was confirmed by Southern blot analysis (Figure 1B) and by PCR amplification (Figure 1C). Furthermore, Northern blot analysis demonstrated a significant reduction of Magi2 transcripts in the heterozygous mutant, but no transcripts in Magi2 $2^{-1-}$ mice (Figure 1D). In addition, the results of the Northern blot analysis were consistent with those of semiquantitative 


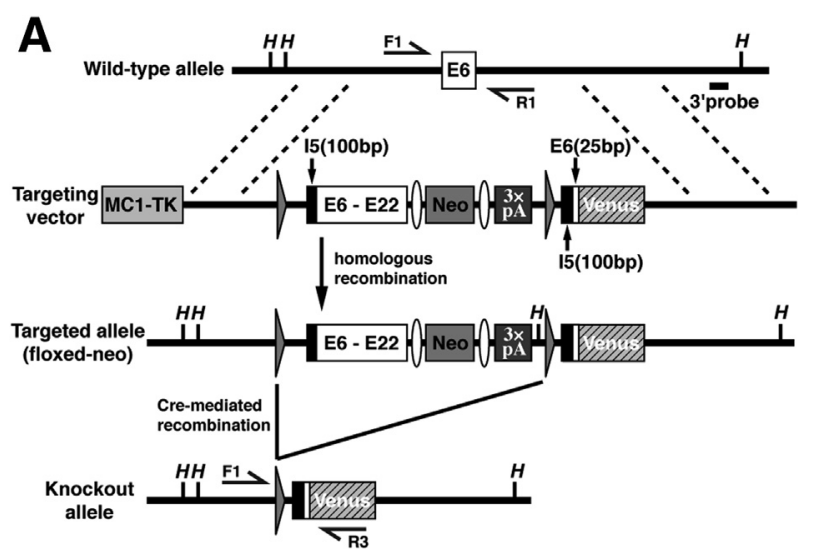

B
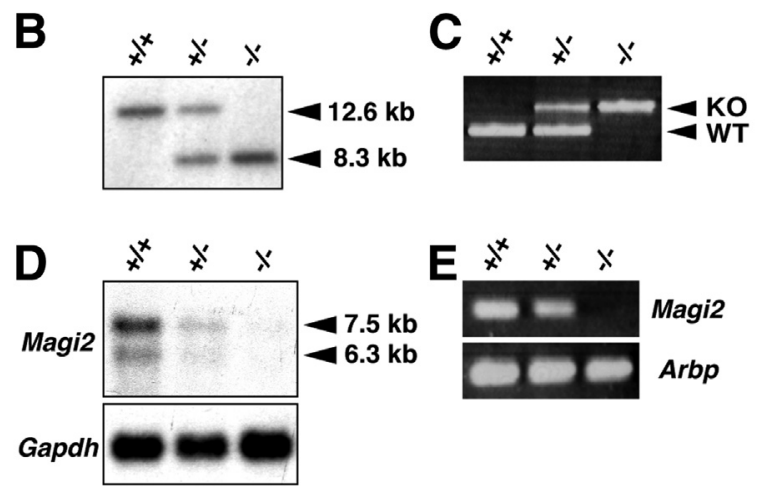

Figure 1 Generation of Magi2 ${ }^{-/-}$mice. A: Wild-type, targeted, and knockout Magi2 loci, and gene targeting constructs. Exons and Magi2 cDNA are indicated by white boxes. The reporter cassette encoding the Venus protein was inserted into exon 6 of the Magi2 gene. As a result, the $5^{\prime}$ portion of exon 6 ( $25 \mathrm{bp}$ ) was connected to the Venus reporter and SV4O polyadenylation sequences. LoxP (gray triangles) and FRT (white ellipses) are also shown, along with positions of restriction enzyme sites and the probes used for Southern blot analyses. B: Southern blot analysis of genomic DNA of littermate progeny from Magi2 ${ }^{+/-}$crosses. HindIII-digested tail DNA was hybridized with the radiolabeled probes shown in A. C: PCR analysis of genomic DNA from mice offspring of $\mathrm{Magi2}^{+/-}$crosses for the knockout (730 bp) and wild-type (550 bp) alleles. D: Northern blot analysis of poly $(A)^{+}$RNA (2 $\mu \mathrm{g}$ per lane) from the brain of $\mathrm{Magi2}^{+/+}$, Magi2 $^{+/-}$, and Magi2 $^{-/-}$mice (D). The blot was sequentially hybridized with Magi2 and Gapdh cDNA probes. RT-PCR analysis of CDNA from the brain of $\mathrm{Magi2}^{+/+}, \mathrm{Magi2}^{+/-}$, and $\mathrm{Magi2}^{-/-}$ mice (E). Arbp was used as internal control. $\mathrm{E}$, exon; $\mathrm{F}$, forward primer; $H$, HindIII; I, intron; K0, knockout; MC1, MC1 promoter; Neo, neomycinresistance gene; $R$, reverse primer; TK, thymidine kinase gene; WT, wildtype; $3 \times$ pA, $3 \times$ Simian virus 40 late polyadenylation signal.

RT-PCR analysis (Figure 1E). From these observations, we concluded that the mutant Magi2 allele that we had constructed causes the functional loss of MAGI-2 protein.

\section{Magi2 $^{-/-}$Mice Are Neonatal Lethal}

The genotypes of offspring from heterozygous mouse crosses at postnatal day $0(\mathrm{P} 0)$ completely followed Mendelian rules of inheritance, with a 63:128:67 ratio of Magi2 $^{+/+}$, Magi2 $^{+/-}$, and Magi2 $2^{-/-}$offspring (Table 1). The Magi $2^{-1-}$ offspring showed no obvious abnormalities in gross appearance at P0 (Supplemental Figure S1A), nor did their body weight differ significantly from that of heterozygous and wild-type mice. Furthermore, the weight of several major organs of Magi2 ${ }^{-1-}$ offspring did not exhibit any abnormality, relative to heterozygous and wild-type mice (Supplemental Figure S1, B-F). However, no Magi ${ }^{-1-}$ mice survived to the day of weaning (3 weeks after birth) (Table 1). We therefore concluded that Magi2 ${ }^{-1-}$ mice are neonatal lethal.

\section{Magi2 $^{-/-}$Mice Exhibit Anuria and Increased Plasma Creatinine}

MAGI-2 protein is highly expressed in certain organs such as brain, kidney, and testis. ${ }^{6}$ In the present study, we examined renal function in $\mathrm{Magi}^{-/-}$mice. In P0 mice, we measured plasma creatinine (which is a breakdown product of creatine phosphate in muscle) as a biomarker of renal function. Most creatinine is filtered out from the blood by the kidney via glomerular filtration and proximal tubular secretion. If filtering by the kidney is deficient or ineffective, the level of creatinine in the blood becomes abnormally high. Plasma creatinine levels of $\mathrm{Magi2}^{-1-}$ mice were significantly higher (fourfold) than in $\mathrm{Magi}^{+/+}$mice (Figure 2A), suggesting that renal function was impaired in Magi $^{-1-}$ mice. In other types of knockout mice, functional abnormalities of the slit diaphragm frequently result in proteinuria. ${ }^{12-16}$ We therefore tried to collect the urine of Magi $^{-1-}$ mice, but could not detect any in the bladder (Figure 2B), indicating severe impairment of renal function. To address kidney abnormalities at the histological level, we examined kidney tissues under a light microscope after hematoxylin and eosin staining and periodic acid-Schiff staining. We did not observe any histological abnormalities of glomeruli in Magi2 ${ }^{-1-}$ mice (Supplemental Figure S2).

\section{Magi2 $^{-/-}$Mice Have Abnormal Podocyte Foot Process Morphology}

To address the pathological mechanisms of abnormal renal function in Magi2 $2^{-1-}$ mice, we performed morphological analysis of the glomeruli at the ultrastructure level by scanning electron microscopy, using the glomeruli of wildtype mice as the control. In wild-type mice, the normal interdigitating network of the foot processes was observed in the glomeruli (Figure 3, A and B). However, Magi2 $2^{-1-}$ mice exhibited abnormal morphology of foot processes (Figure 3, C and D): the foot processes were shortened, and the interdigitating network was not well organized.

Table 1 Mendelian Inheritance of Pups Produced by Breeding Pairs of Magi2 ${ }^{+/-}$Mice and Neonatal Lethality of Magi2 ${ }^{-/-}$Pups

\begin{tabular}{|c|c|c|c|c|c|}
\hline \multirow[b]{2}{*}{ Age } & \multirow[b]{2}{*}{$n$} & \multicolumn{3}{|c|}{ Genotype } & \multirow[b]{2}{*}{ Ratio } \\
\hline & & $+/+$ & $+/-$ & $-/-$ & \\
\hline Newborn (P0) & 258 & 63 & 128 & 67 & $1.00: 2.03: 1.06$ \\
\hline Weaning (3 wk) & 424 & 138 & 286 & 0 & $1.00: 2.07: 0.00$ \\
\hline
\end{tabular}

The genotypes of newborn pups and weaned pups were analyzed separately. 

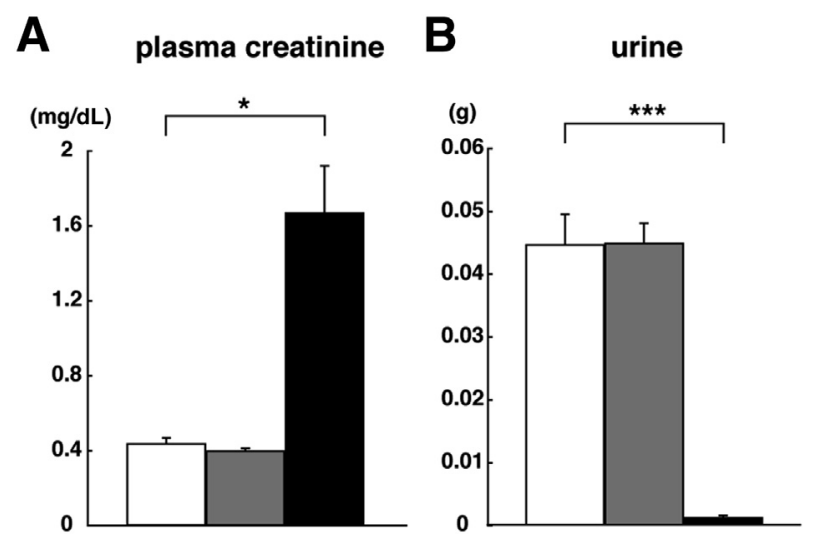

Figure 2 Magi2 $^{-1-}$ mice exhibit increased plasma creatinine and anuria. A: The plasma creatinine level of Magi2 $^{-1-}$ mice (black bars) was approximately fourfold higher than that of Magi2 $^{+/+}$(white bars) or Magi2 ${ }^{+/-}$(gray bars) mice. B: Magi2 $^{-1-}$ mice exhibited a lack of urine in the bladder, in contrast to $\mathrm{Magi2}^{+/+}$and Magi2 $^{+/-}$mice. Data are expressed as means \pm SEM. $n=3(+/+, \mathbf{A}) ; n=6(-/-) ; n=8(+/+, \mathbf{B}) ; n=17(+/-, \mathbf{A})$; $n=24(+/-$, B $) .{ }^{*} P<0.05 ;{ }^{* *} P<0.001$, Student's $t$-test.

To further address the glomerular abnormalities of Magi $2^{-1-}$ mice, we examined the ultrastructure of glomeruli with transmission electron microscopy. The arrangement and morphology of podocyte cell bodies looked normal in both Magi2 $^{+/+}$and Magi2 ${ }^{-/-}$mice (Figure 3, F and I). Slit diaphragms (Figure 3, $\mathrm{G}$ and $\mathrm{H}$ ) are ordinarily observed as gaps between foot processes, which normally exit at the basal side in $\mathrm{Magi2}^{+/+}$mice. Surprisingly, we could not observe clear slit diaphragms in glomeruli of $\mathrm{Magi}^{-1-}$ mice, because fusion and/or adhesion of the foot processes had occurred (Figure 3, J and K). For quantitative evaluation, we determined the gap space between foot processes in Magi $^{+/+}$and Magi2 $2^{-/-}$mice (Figure 3E). The gap space in Magi $^{-1-}$ mice was significantly narrowed. From these results, we concluded that the slit diaphragms in Magi2 ${ }^{-1-}$ mice are impaired.

\section{Nephrin and Dendrin Expression in the Glomeruli of Magi2 $^{-/-}$Mice Is Dramatically Reduced}

The slit diaphragm is composed of a complex of several proteins. One of these, nephrin, is a transmembrane protein that is a main structural component of the slit diaphragm. ${ }^{17}$ MAGI-2 is reported to interact with slit diaphragm components, including nephrin. ${ }^{18}$ Interestingly, loss of function of components in the slit diaphragm sometimes affects expression of other components. For example, Yaddanapudi et $\mathrm{al}^{19}$ reported that loss of function of CD2AP induces a dramatic reduction of dendrin, which is another component of the slit diaphragm.

Using immunohistochemistry, we confirmed the localization of MAGI-2 protein at the slit diaphragm in wild-type
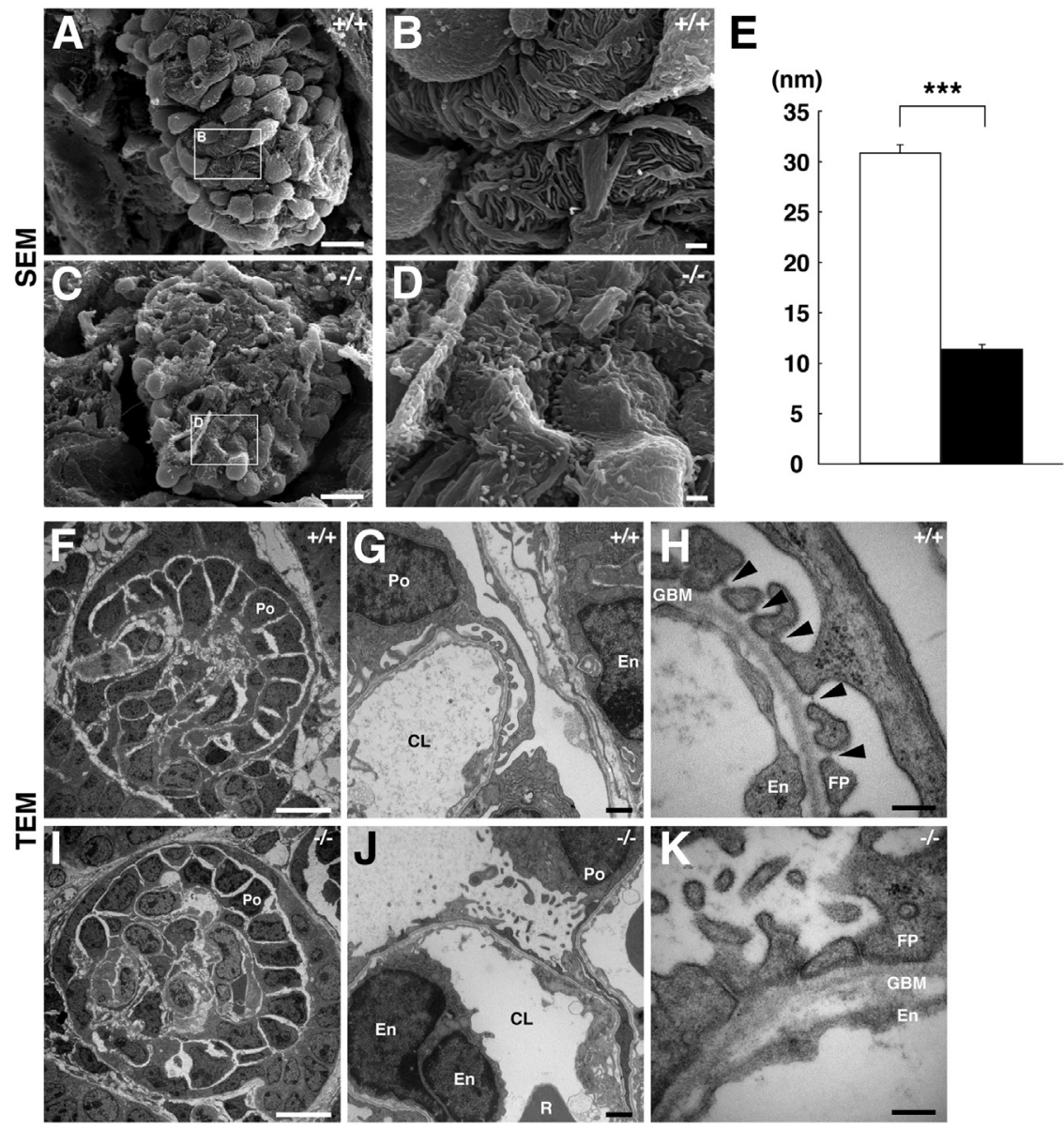

Figure 3 Magi2 $^{-/}$mice exhibit abnormal morphology of podocyte foot processes. A-D: Scanning electron micrographs of podocyte foot processes in $\mathrm{Magi2}^{+/+}$mice (A and $\mathbf{B}$ ) and $\mathrm{Magi2}^{-/-}$mice (C and D). Magi2 ${ }^{-/-}$mice exhibit abnormal morphology. Boxed regions in $\mathbf{A}$ and $\mathbf{C}$ are shown at higher magnification in $\mathbf{B}$ and $\mathbf{D}$, respectively. $\mathbf{E}$ : The distance between foot processes is dramatically decreased in Magi2 $^{-/-}$mice (black bars), compared with Magi2 $^{+/+}$ (white bars). $\mathbf{F}-\mathbf{K}$ : Microstructure of slit diaphragm in Magi2 $^{+/+}$mice $(\mathbf{F}-\mathbf{H})$ and Magi2 $^{-/-}$mice $(\mathbf{I}-\mathbf{K})$ by transmission electron microscopy. In $\mathbf{H}$, the slit diaphragm is indicated by arrowheads. Data are expressed as means \pm SEM. $n=46(+/+) ; n=37$ $(-/-)$. ${ }^{* * *} P<0.001$, Student's $t$-test. Scale bars: $10 \mu \mathrm{m}(\mathbf{A}, \mathbf{C}, \mathbf{F}$, and I); $1 \mu \mathrm{m}$ (B, D, G, and J); $200 \mathrm{~nm}$ $(\mathbf{H}$ and $\mathbf{K}) . \mathrm{CL}$, capillary lumen; $\mathrm{En}$, endothelial cell; FP, foot process; GBM, glomerular basement membrane; Po, podocyte; R, red blood cell. 


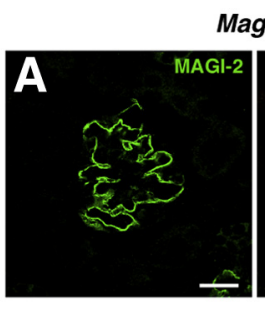

nephrin
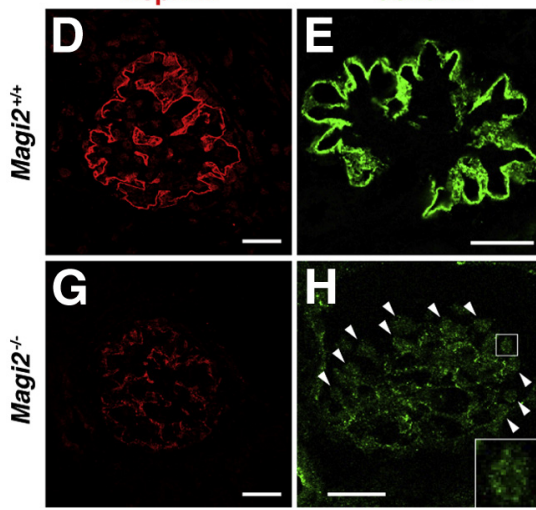

Magi2\%

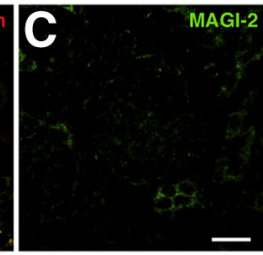

DAPI dendrin WT-1
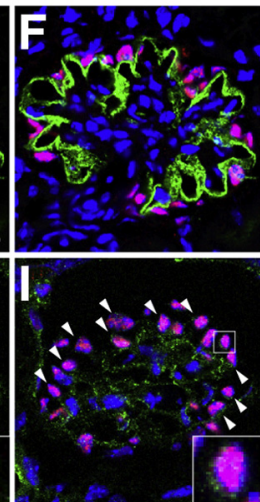

Figure 4 Nephrin and dendrin are dramatically reduced in glomeruli of Magi2 $^{-1-}$ mice. A and B: Immunodetection of MAGI-2 (A) and MAGI-2 with nephrin (B) in Magi2 $^{+/+}$mice. The expression patterns of MAGI-2 and nephrin were almost perfectly overlapping. C: MAGI-2 was not detected in Magi $^{-/-}$mice. D-I: Nephrin and dendrin levels were normal in the slit diaphragm of Magi2 $^{+/+}$mice $(\mathbf{D}-\mathbf{F})$, but a remarkable reduction of these molecules was observed in Magi2 ${ }^{-1-}$ mice (G-I). Dendrin translocated into nuclei in Magi2 $^{-/}$mice (H and $\mathbf{I}$, arrowheads). WT-1 was used as a marker for the podocyte nucleus (F and $\mathbf{I})$. Scale bar $=20 \mu \mathrm{m}$.

mice (Figure 4A), which suggested that it functions in the slit diaphragm in the wild-type condition. To investigate localization of MAGI-2 in the slit diaphragm of Magi2 ${ }^{+/+}$ mice, we used double staining with antibodies against MAGI-2 and nephrin. The results showed identical localization of MAGI-2 and nephrin (Figure 4, A and B), indicating the potential association of MAGI-2 protein with slit diaphragm-composing proteins, such as nephrin. As expected, MAGI-2 was not detected in $\mathrm{Magi2}^{-1-}$ mice (Figure 4C). MAGI-2 was not observed in renal tubules (data not shown).

The expression of further components of the slit diaphragm was detected by immunohistochemistry, including dendrin, CD2AP, podocin, synaptopodin, WT-1, and podocalyxin. All of these components were detected at the slit diaphragm or in the nuclei of podocytes in Magi $2^{+/+}$ mice (Figure 4, D-F, and Supplemental Figure S3, A-D, I). However, expression of nephrin and dendrin was dramatically reduced in Magi2 ${ }^{-1-}$ mice, although other components (podocin, synaptopodin, WT-1, CD2AP, and podocalyxin) were present at near-normal levels (Figure 4, G-I, and Supplemental Figure S3, E-H, L). In addition, dendrin was detected in the nuclei in $\mathrm{Magi}^{-1-}$ mice (Figure 4, H and I). From these results, we concluded that loss of function of MAGI-2 protein affects the expression level and cellular localization of diaphragm-related proteins, including nephrin and dendrin.
Loss of Function of MAGI-2 Results in Elevated Expression of CatL

MAGI-2-deficient mice exhibited a dramatic reduction in nephrin and dendrin expression, along with nuclear translocation of dendrin. Yaddanapudi et $\mathrm{al}^{19}$ reported that translocation of dendrin induced elevated expression of the lysosomal cysteine proteinase cathepsin L (CatL) in kidney podocytes. We examined CatL expression in kidney by realtime RT-PCR. Ctsl mRNA (Ctsl encodes CatL) was measured in total RNA obtained from $\mathrm{Magi2}^{+/+}$and $\mathrm{Magi2}^{-/-}$ mice (Figure $5 \mathrm{~A}$ ) and was found to be significantly higher in Magi $^{-l-}$ mice than in Magi2 $2^{+/+}$mice. We also evaluated expression of Nphs 1 mRNA ( $N p h s 1$ encodes nephrin) and found almost identical expression in $\mathrm{Magi}^{+/+}$and Magi $^{-1-}$ mice. The expression level of Nphs 1 mRNA measured by RT-PCR (Figure 5A) did not agree with that indicated by immunostaining (Figure 4, D and G), perhaps because of accelerated degradation of nephrin protein in Magi2 $^{-1-}$ mice.

To provide further evidence supporting a reduced level of nephrin in the slit diaphragm of Magi2 $2^{-1-}$ mice, we performed
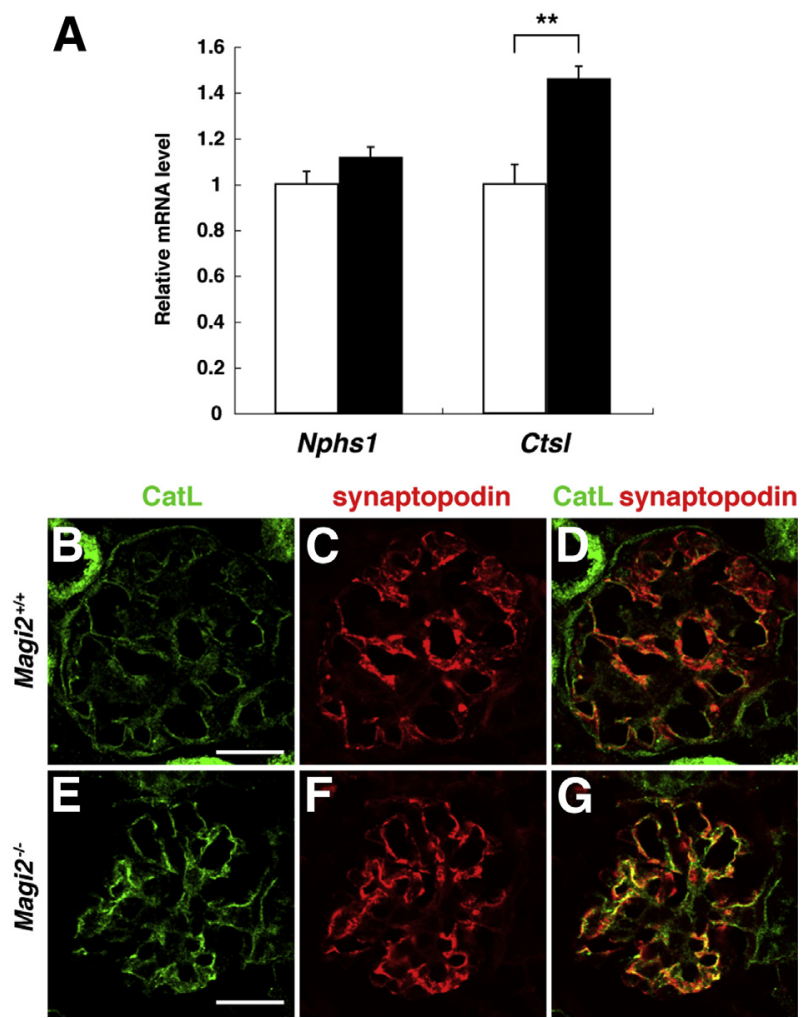

Figure 5 MAGI-2-induced expression of cytosolic CatL is defective. A: Quantitative RT-PCR of Nphs1 and Ctsl indicates that Ctsl mRNA significantly increases in Magi2 ${ }^{-1-}$ (black bars) mice, compared with that of Magi $^{+/+}$mice (white bars), but Nphs1 mRNA levels in Magi2 $^{-/-}$mice are not significantly changed. B-G: Immunohistochemical analysis of CatL and synaptopodin. Up-regulation of CatL is observed in the slit diaphragm of Magi2 $^{-1-}$ mice. Synaptopodin was used as a slit-diaphragm marker. Data are expressed as means \pm SEM. ${ }^{* *} P<0.01$, Student's $t$-test. Scale bar $=$ $20 \mu \mathrm{m}$. CatL, cathepsin L. 

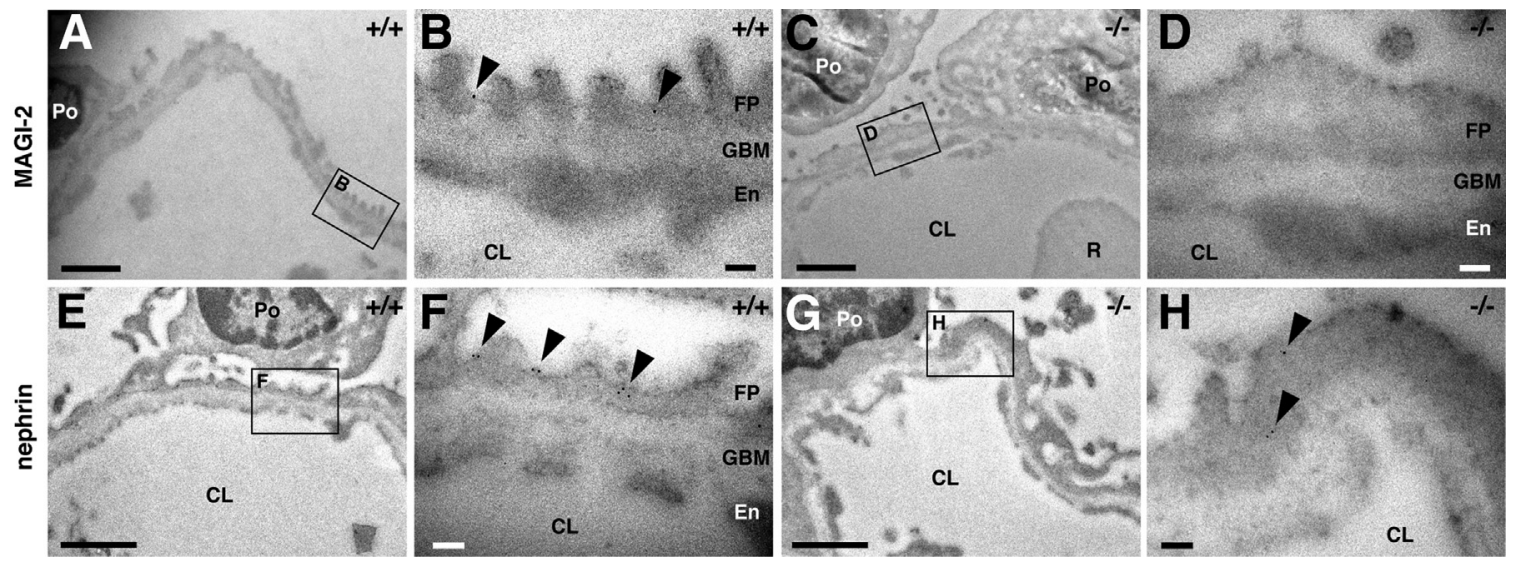

Figure 6 Immunoelectron micrographs of slit diaphragms. A-D: MAGI-2 immunological signals (arrowheads) were detected in slit diaphragms of Magi2 $2^{+/+}$ mice (A and $\mathbf{B})$, but not those of Magi2 ${ }^{-/-}$mice (C and D). E-H: Nephrin immunological signals (arrowheads) were detected in slit diaphragms of Magi2 ${ }^{+/+}$mice $(\mathbf{E}$ and $\mathbf{F})$ and in Magi2 $^{-1-}$ mice, in which the signals were decreased and ectopic localization was observed ( $\mathbf{G}$ and $\mathbf{H}$, arrowheads). Boxed regions are shown at higher magnification in the adjacent panel with a matching letter. Scale bars: $1 \mu \mathrm{m}(\mathbf{A}, \mathbf{C}, \mathbf{E}$, and $\mathbf{G}) ; 100 \mathrm{~nm}(\mathbf{B}, \mathbf{D}, \mathbf{F}$, and $\mathbf{H})$.

immunoelectron microscopy using immunogold-labeled antibody. MAGI-2 and nephrin signals were detected in the slit diaphragms of $\mathrm{Magi2}^{+/+}$mice (Figure 6, A, B, E, and F). In Magi2 ${ }^{-l-}$ mice, however, the MAGI-2 signal was not detected, and nephrin expression was both decreased and ectopic (Figure 6, C, D, G, and H). To further address the effect of loss of MAGI-2 function, we examined CatL in the kidney of Magi2 ${ }^{+/+}$and Magi2 $2^{-/-}$mice by immunostaining. CatL is normally expressed in glomeruli of $\mathrm{Magi}^{+/+}$mice (Figure 5, $\mathrm{B}$ and $\mathrm{D})$. Interestingly, relatively high expression of CatL was observed in glomeruli of $\mathrm{Magi}^{-1-}$ mice (Figure 5, E and G), compared with compared with the wild type. Synaptopodin was used as a slit-diaphragm marker (Figure 5, C and F). CatL significantly colocalized with synaptopodin.

\section{MAGI-2 Defect Alters Expression Patterns of Cell Adherence Molecules}

We next focused on change in cytosolic CatL, which is reported to induce cleavage of the dynamin GTPase and the actin-associated adapter synaptopodin, resulting in rearrangement of the actin cytoskeleton in the podocyte. ${ }^{20,21}$ We suspected that there might be some alteration in the distribution of cytoskeletal-related protein in the foot process. We performed immunostaining of tight junction proteins in the kidney podocyte and detected the localization of claudin-5 and ZO-1 at the slit diaphragm in $\mathrm{Magi2}^{+/+}$mice (Figure 7, $\mathrm{A}$ and B, and Supplemental Figure S3J). In Magi2 ${ }^{-1-}$ mice, interestingly, claudin-5 was detected not only in the slit diaphragm (merged

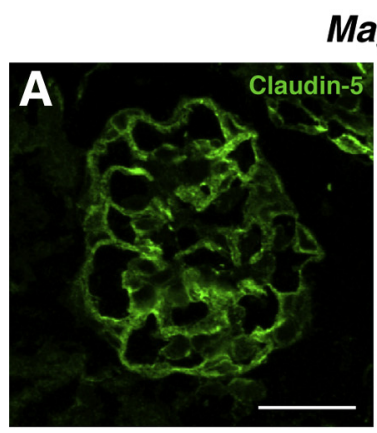

Magi2 $^{+/+}$
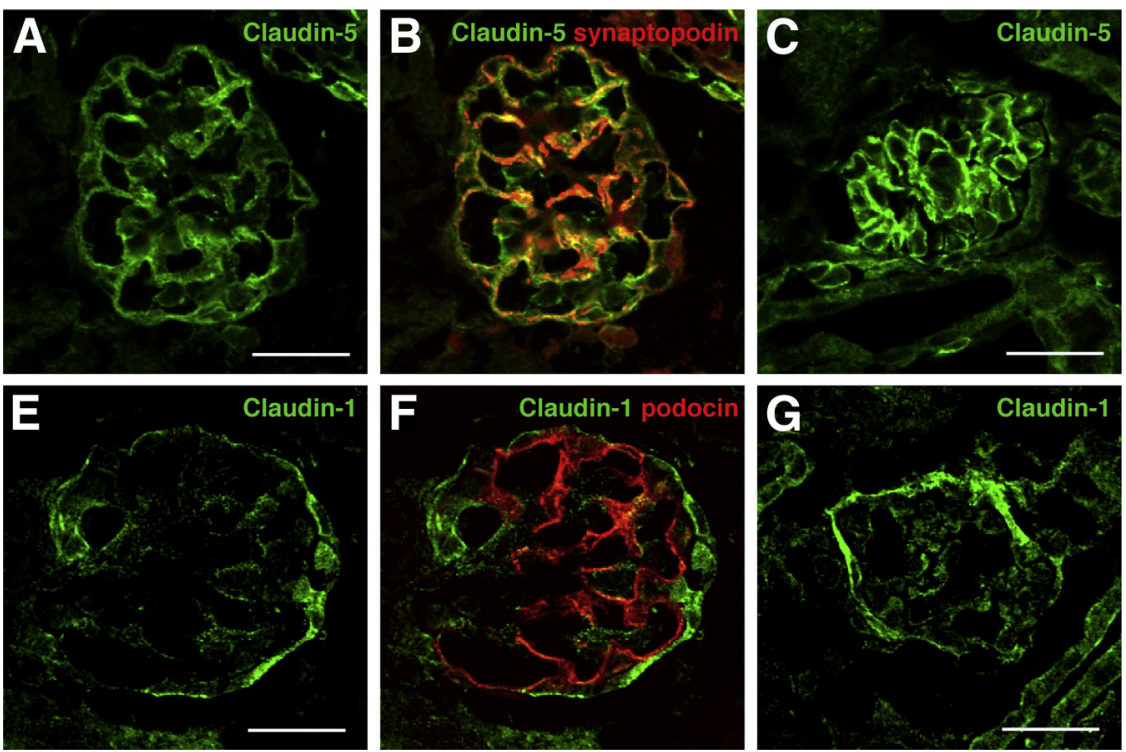

Magi2 ${ }^{-/-}$
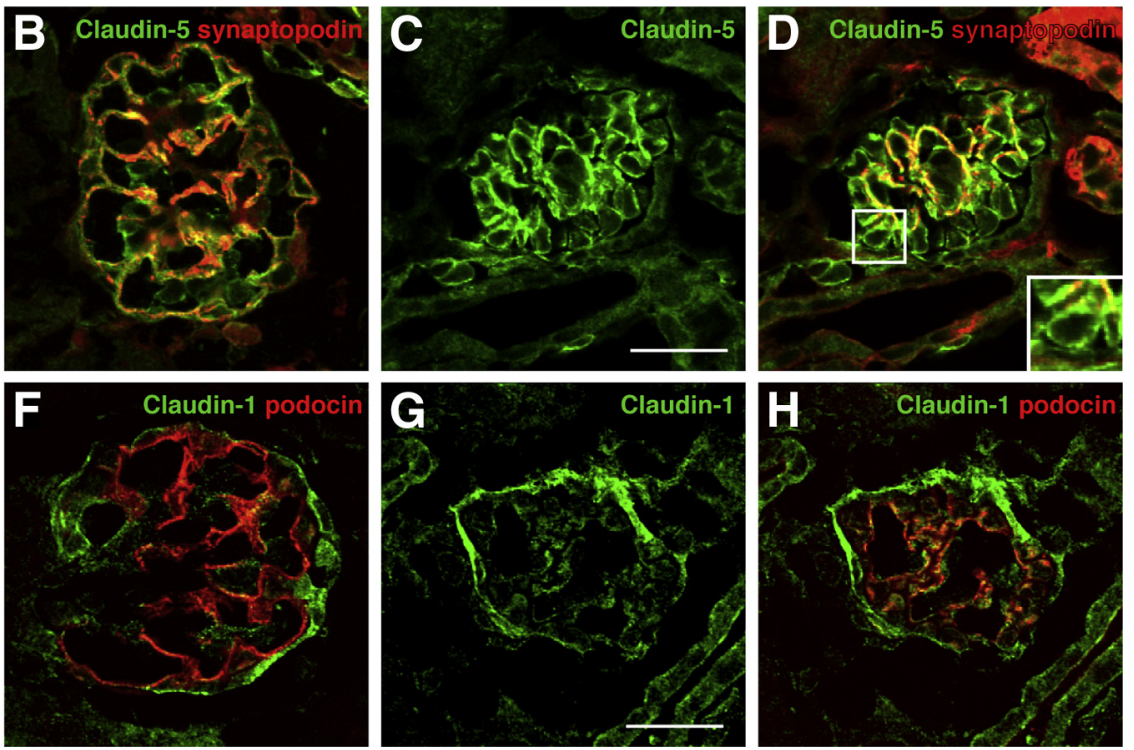

Figure 7 MAGI-2 defect alters expression patterns of cell adherence molecules. Immunohistochemical analyses of claudin-5 and synaptopodin (A-D) and claudin-1 and podocin (E-H). In Magi2 ${ }^{-/}$mice, claudin-5 is detected not only in slit diaphragms, but also between the contact surfaces of podocyte cell bodies, as seen at higher magnification (D, inset). Fluorescence intensity of claudin-1 in the slit diaphragms of Magi2 ${ }^{-1-}$ mice is slightly enhanced compared with that in Magi2 ${ }^{+/+}$mice (H). Synaptopodin and podocin were used as slit-diaphragm markers. Scale bar $=20 \mu \mathrm{m}$. 

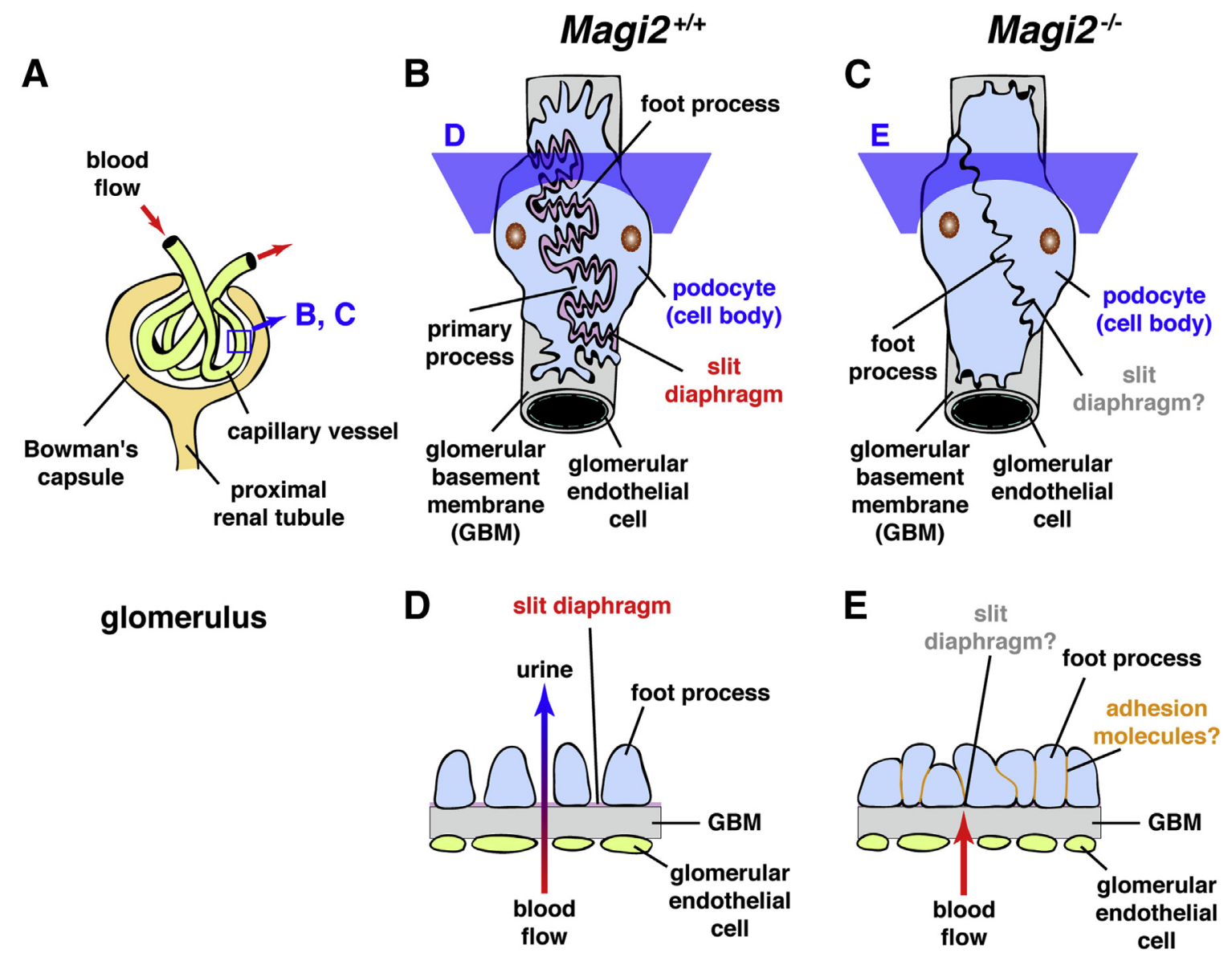

Figure 8 Schematics for the diaphragm of the glomerulus in Magi2 ${ }^{+/+}$and Magi2 ${ }^{-/-}$mice. A: Structure of the glomerulus. The boxed region is shown in detail in B and C. B-E: In wild-type mice (B and D), the slit diaphragm, which consists of a gap between podocyte foot processes, has an important role in producing primary urine from blood flow. In the knockout mice ( $\mathbf{C}$ and $\mathbf{E}$ ), the gap is blocked because of stacking and fusion of the foot processes. In $\mathbf{B}$ and $\mathbf{C}$, the transparent plane indicates the cross-sectional area on which the corresponding detailed schematic ( $\mathbf{D}$ and $\mathbf{E})$ is based. Schematics are adapted from Ihara et al. ${ }^{6}$

with synaptopodin), but also between the contact surfaces of podocyte cell bodies (Figure 7, C and D). ZO-1 was intact in Magi2 $^{-1-}$ mice (Supplemental Figure S3M). MAGI-2 was also reported as a component of the adherens junction complex. $^{22,23}$ However, we confirmed that the expression pattern of $\beta$-catenin did not change (Supplemental Figure S3, K and $\mathrm{N})$. Instead, in the slit diaphragm of $\mathrm{Magi2}^{-1-}$ mice we observed low levels of expression of claudin-1, which is usually expressed in the epithelial cells of Bowman's capsu$\mathrm{le}^{24-26}$ (to prevent urine leaking from the capsule) (Figure 7, E and F). From these results, we concluded that loss of functional MAGI-2 at the slit diaphragm complex results in increased CatL and potentially contributes to disordering of foot processes and to altered expression pattern of adhesion molecules.

\section{Discussion}

The potential role of MAGI-2 protein in neuronal tissue is suggested by earlier research, in which knockout of the $\alpha$ form of MAGI-2 gave rise to abnormal spine morphogenesis. ${ }^{3}$ However, we need to focus on the $\alpha, \beta$, and $\gamma$ splicing variants of MAGI-2, bearing in mind that insertion of the Venus reporter cassette is expected to result in loss of the important
WW and PDZ C-terminal functional domains of the MAGI-2 protein.

Previously, we reported the detailed tissue distribution of MAGI-2 in the Venus knock-in mouse. ${ }^{6}$ Our established Venus knock-in mouse expresses the Venus fusion protein in all splicing forms of MAGI-2, because the Venus expression cassette was inserted into exon 6 , which is present in all MAGI-2 splicing forms. Furthermore, the high fluorescence intensity of the Venus protein allows visualization of the detailed distribution of all MAGI-2 forms throughout the organs. MAGI-2 was highly expressed in various types of neurons in brain. We also detected MAGI-2 protein localization in testis spermatids. In addition to the brain and testis, we also reported expression of MAGI-2 in the kidney glomerulus, and its localization in the podocyte.

In the present study, we observed neonatal lethality and anuria in our knockout mice, which reveal the critical function of the MAGI-2 protein in the kidney. We retrieved dead neonates as possible, and analyzed each genotype. Of the dead neonates analyzed, 36/52 (69\%) were $\mathrm{Magi2}^{-1-}$, whereas the genotype of living neonates at P0 completely followed Mendelian rules of inheritance (the proportion of Magi $^{-1-}$ mice was 26\%). Moreover, all deaths of Magi2 ${ }^{-1-}$ 
mice occurred within 48 hours after birth. We therefore concluded that Magi2 ${ }^{-l-}$ mice exhibit neonatal lethality, unable to survive for more than a few days after birth. Furthermore, we showed by electron microscopy on the kidney of knockout mice that the structure of the slit diaphragm was impaired. Fusion of the podocyte foot processes resulted in loss of the normal slit diaphragm structure. Normally, blood is filtered through the slit diaphragm in the kidney glomerulus to produce primary urine. The anuria phenotype we observed in our knockout mice may be explained by the abnormal morphology of the slit diaphragm. In addition, we confirmed increasing plasma creatinine levels in Magi2 $2^{-1-}$ mice at P0. Taken together, these results indicate that the renal function of excretion of waste matter was entirely lost, and that this caused neonatal lethality of the Magi2 $2^{-1-}$ mice.

In accord with this idea, we showed that loss of MAGI-2 protein function induces nuclear localization of dendrin and elevated expression of CatL. CatL induced cleavage of the dynamin GTPase and the actin-associated adapter synaptopodin, resulting in rearrangement of the actin cytoskeleton in the podocyte. ${ }^{20,21}$ We expected to find that the anuria was due to changed expression patterns in cell adherence molecules between foot processes. Interaction between MAGI-2 and tight junction or adherens junction proteins in epithelial cells has been reported. ${ }^{22,23}$ We performed immunostaining of claudin-5, ZO-1, and $\beta$-catenin in the kidney podocyte. Both ZO-1 and $\beta$-catenin were intact in the slit diaphragm of Magi $^{-1-}$ mice (Supplemental Figure S3, M and N); however, claudin-5 was detected not only in the slit diaphragm (merged with synaptopodin), but also between the contact surfaces of podocyte cell bodies (Figure 7, C and D). In addition, we observed low-level expression of claudin-1 in the slit diaphragm of Magi2 ${ }^{-1-}$ mice (Figure 7, G and H). Alteration in expression patterns of claudin-5 and claudin-1, which are responsible for adhesion of foot processes, is one of the abnormalities that possibly caused fusion of the podocyte foot processes and the abnormal structure of the slit diaphragm, ultimately leading to the anuria phenotype in Magi $^{-1-}$ mice.

Interestingly, the MAGI-2 knockout mice exhibited decreased immunoreactivity of nephrin, compared with the wild type (Figure 4, D and G). In contrast to the immunostaining results, measurement of Nphs I mRNA levels showed no difference between $\mathrm{Magi2}^{+/+}$and $\mathrm{Magi2}^{-/-}$ mice (Figure 5A). A reasonable explanation for this discrepancy would be that nephrin is regulated at the protein level. Indeed, nephrin protein is controlled at the protein level by endocytosis. ${ }^{27-29}$ We suggest that the loss of functional MAGI-2 accelerates the degradation of nephrin protein, but does not affect nephrin transcription.

In the present study, we discovered a critical renal function of MAGI-2 protein, using Magi2 knockout mice. The phenotype obtained quite clearly demonstrates the importance of this gene product in the maintenance of renal function. However, there are still unanswered questions about differences in the phenotype (as, for example, the difference in proteinuria and anuria). In previous studies of slit diaphragm-related proteins, such as nephrin and dynamin, the knockout mice exhibited proteinuria, but not anuria. Our present data cannot explain the phenotypic differences between proteinuria and anuria at the cellular and molecular level.

We summarize our findings in Figure 8. Primary urine is usually produced from blood flow at the kidney glomerulus (Figure 8A). In wild-type mice (Figure 8, B and D), the slit diaphragm, which composes the gap in the podocyte foot processes, has an important role in kidney function. The morphology of the podocyte foot process was abnormal in Magi $2^{-/-}$mice; the podocyte could not maintain the slit diaphragm structure, because of stacking and fusion of the foot processes (Figure 8, C and E). One possible molecular mechanism for the abnormal podocyte foot processes in $\mathrm{Magi2}^{-1-}$ mice is abnormal distribution of one or more types of cell adhesion-related molecule. In ongoing work, we are trying to detect expression of E-cadherin and P-cadherin, to explore further evidences of cell adhesion-related abnormalities. Although we do not yet have conclusive data, the expression status of these adhesion-related molecules may reveal the molecular pathogenesis of how functional loss of MAGI-2 affects the podocyte.

Our present study is the first to demonstrate that MAGI-2 has an essential role in kidney function and maintenance of the structure of the slit diaphragm of the glomerulus. In further studies, conditional knockouts could be created by crosses with transgenic mice expressing Cre only within the podocyte. ${ }^{30-34}$ Functional loss of MAGI-2 in these mutants would be specifically induced only within the podocyte; this would contribute to a fuller understanding of the phenotypic differences we observed.

\section{Acknowledgments}

We thank Dr. Kan Katayama (Karolinska Institute, Stockholm, Sweden) for anti-nephrin antibody; Prof. Andrey Shaw (Washington University School of Medicine, St. Louis, MO) for anti-CD2AP antibody; Prof. Emiko Isogai (Tohoku University, Sendai, Japan) for technical help in generating anti-MAGI-2 antibody; Terumi Shibata, Kaori Takahashi, Junichi Nakamoto, and Mitsutaka Yoshida (Juntendo University Graduate School of Medicine, Tokyo, Japan) for excellent technical assistance in electron microscopy; and Dr. Kaoru Inoue for technical support in histological analysis of kidney sections.

\section{Supplemental Data}

Supplemental material for this article can be found at http://dx.doi.org/10.1016/j.ajpath.2014.06.019.

\section{References}

1. Hirao K, Hata Y, Ide N, Takeuchi M, Irie M, Yao I, Deguchi M, Toyoda A, Sudhof TC, Takai Y: A novel multiple PDZ domain-containing molecule 
interacting with N-methyl-D-aspartate receptors and neuronal cell adhesion proteins. J Biol Chem 1998, 273:21105-21110

2. Sumita K, Sato Y, Iida J, Kawata A, Hamano M, Hirabayashi S, Ohno K, Peles E, Hata Y: Synaptic scaffolding molecule (S-SCAM) membrane-associated guanylate kinase with inverted organization (MAGI)-2 is associated with cell adhesion molecules at inhibitory synapses in rat hippocampal neurons. J Neurochem 2007, 100:154-166

3. Iida J, Ishizaki H, Okamoto-Tanaka M, Kawata A, Sumita K, Ohgake S, Sato Y, Yorifuji H, Nukina N, Ohashi K, Mizuno K, Tsutsumi T, Mizoguchi A, Miyoshi J, Takai Y, Hata Y: Synaptic scaffolding molecule alpha is a scaffold to mediate N-methyl-D-aspartate receptor-dependent RhoA activation in dendrites. Mol Cell Biol 2007, 27:4388-4405

4. Hirao K, Hata Y, Yao I, Deguchi M, Kawabe H, Mizoguchi A, Takai Y: Three isoforms of synaptic scaffolding molecule and their characterization. Multimerization between the isoforms and their interaction with N-methyl-D-aspartate receptors and SAP90/PSD-95associated protein. J Biol Chem 2000, 275:2966-2972

5. Nagai T, Ibata K, Park ES, Kubota M, Mikoshiba K, Miyawaki A: A variant of yellow fluorescent protein with fast and efficient maturation for cell-biological applications. Nat Biotechnol 2002, 20:87-90

6. Ihara K, Nishimura T, Fukuda T, Ookura T, Nishimori K: Generation of Venus reporter knock-in mice revealed MAGI-2 expression patterns in adult mice. Gene Expr Patterns 2012, 12:95-101

7. Takayanagi Y, Yoshida M, Bielsky IF, Ross HE, Kawamata M, Onaka T, Yanagisawa T, Kimura T, Matzuk MM, Young LJ, Nishimori K: Pervasive social deficits, but normal parturition, in oxytocin receptordeficient mice. Proc Natl Acad Sci USA 2005, 102:16096-16101

8. Sakairi T, Abe Y, Jat PS, Kopp JB: Cell-cell contact regulates gene expression in CDK4-transformed mouse podocytes. Am J Physiol Renal Physiol 2010, 299:F802-F809

9. Lerner I, Hermano E, Zcharia E, Rodkin D, Bulvik R, Doviner V, Rubinstein AM, Ishai-Michaeli R, Atzmon R, Sherman Y, Meirovitz A, Peretz T, Vlodavsky I, Elkin M: Heparanase powers a chronic inflammatory circuit that promotes colitis-associated tumorigenesis in mice. J Clin Invest 2011, 121:1709-1721

10. Asanuma K, Akiba-Takagi M, Kodama F, Asao R, Nagai Y, Lydia A, Fukuda H, Tanaka E, Shibata T, Takahara H, Hidaka T, Asanuma E, Kominami E, Ueno T, Tomino Y: Dendrin location in podocytes is associated with disease progression in animal and human glomerulopathy. Am J Nephrol 2011, 33:537-549

11. Inaga S, Katsumoto T, Tanaka K, Kameie T, Nakane H, Naguro T: Platinum blue as an alternative to uranyl acetate for staining in transmission electron microscopy. Arch Histol Cytol 2007, 70:43-49

12. Donoviel DB, Freed DD, Vogel H, Potter DG, Hawkins E, Barrish JP, Mathur BN, Turner CA, Geske R, Montgomery CA, Starbuck M, Brandt M, Gupta A, Ramirez-Solis R, Zambrowicz BP, Powell DR: Proteinuria and perinatal lethality in mice lacking NEPH1, a novel protein with homology to NEPHRIN. Mol Cell Biol 2001, 21:4829-4836

13. Putaala H, Soininen R, Kilpeläinen P, Wartiovaara J, Tryggvason K: The murine nephrin gene is specifically expressed in kidney, brain and pancreas: inactivation of the gene leads to massive proteinuria and neonatal death. Hum Mol Genet 2001, 10:1-8

14. Kos CH, Le TC, Sinha S, Henderson JM, Kim SH, Sugimoto H, Kalluri R, Gerszten RE, Pollak MR: Mice deficient in alpha-actinin-4 have severe glomerular disease. J Clin Invest 2003, 111:1683-1690

15. Roselli S, Heidet L, Sich M, Henger A, Kretzler M, Gubler MC, Antignac C: Early glomerular filtration defect and severe renal disease in podocin-deficient mice. Mol Cell Biol 2004, 24:550-560

16. Shih NY, Li J, Karpitskii V, Nguyen A, Dustin ML, Kanagawa O, Miner JH, Shaw AS: Congenital nephrotic syndrome in mice lacking CD2-associated protein. Science 1999, 286:312-315

17. Ruotsalainen V, Ljungberg P, Wartiovaara J, Lenkkeri U, Kestilä M, Jalanko H, Holmberg C, Tryggvason K: Nephrin is specifically located at the slit diaphragm of glomerular podocytes. Proc Natl Acad Sci USA 1999, 96:7962-7967

18. Lehtonen S, Ryan JJ, Kudlicka K, Iino N, Zhou H, Farquhar MG: Cell junction-associated proteins IQGAP1, MAGI-2, CASK, spectrins, and alpha-actinin are components of the nephrin multiprotein complex. Proc Natl Acad Sci USA 2005, 102:9814-9819

19. Yaddanapudi S, Altintas MM, Kistler AD, Fernandez I, Möller CC, Wei C, Peev V, Flesche JB, Forst AL, Li J, Patrakka J, Xiao Z, Grahammer F, Schiffer M, Lohmüller T, Reinheckel T, Gu C, Huber TB, Ju W, Bitzer M, Rastaldi MP, Ruiz P, Tryggvason K, Shaw AS, Faul C, Sever S, Reiser J: CD2AP in mouse and human podocytes controls a proteolytic program that regulates cytoskeletal structure and cellular survival [Erratum appeared in J Clin Invest 2012, 122:780.]. J Clin Invest 2011, 121:3965-3980

20. Sever S, Altintas MM, Nankoe SR, Möller CC, Ko D, Wei C, Henderson J, del Re EC, Hsing L, Erickson A, Cohen CD, Kretzler M, Kerjaschki D, Rudensky A, Nikolic B, Reiser J: Proteolytic processing of dynamin by cytoplasmic cathepsin $\mathrm{L}$ is a mechanism for proteinuric kidney disease. J Clin Invest 2007, 117:2095-2104

21. Faul C, Donnelly M, Merscher-Gomez S, Chang YH, Franz S, Delfgaauw J, Chang JM, Choi HY, Campbell KN, Kim K, Reiser J, Mundel P: The actin cytoskeleton of kidney podocytes is a direct target of the antiproteinuric effect of cyclosporine A. Nat Med 2008, 14:931-938

22. Wu X, Hepner K, Castelino-Prabhu S, Do D, Kaye MB, Yuan XJ, Wood J, Ross C, Sawyers CL, Whang YE: Evidence for regulation of the PTEN tumor suppressor by a membrane-localized multi-PDZ domain containing scaffold protein MAGI-2. Proc Natl Acad Sci USA 2000, 97:4233-4238

23. Subauste MC, Nalbant P, Adamson ED, Hahn KM: Vinculin controls PTEN protein level by maintaining the interaction of the adherens junction protein beta-catenin with the scaffolding protein MAGI-2. J Biol Chem 2005, 280:5676-5681

24. Kiuchi-Saishin Y, Gotoh S, Furuse M, Takasuga A, Tano Y, Tsukita S: Differential expression patterns of claudins, tight junction membrane proteins, in mouse nephron segments. J Am Soc Nephrol 2002, 13:875-886

25. Ohse T, Pippin JW, Vaughan MR, Brinkkoetter PT, Krofft RD, Shankland SJ: Establishment of conditionally immortalized mouse glomerular parietal epithelial cells in culture. J Am Soc Nephrol 2008, 19:1879-1890

26. Appel D, Kershaw DB, Smeets B, Yuan G, Fuss A, Frye B, Elger M, Kriz W, Floege J, Moeller MJ: Recruitment of podocytes from glomerular parietal epithelial cells. J Am Soc Nephrol 2009, 20:333-343

27. Quack I, Rump LC, Gerke P, Walther I, Vinke T, Vonend O, Grunwald T, Sellin L: beta-Arrestin2 mediates nephrin endocytosis and impairs slit diaphragm integrity. Proc Natl Acad Sci USA 2006 103:14110-14115

28. Qin XS, Tsukaguchi H, Shono A, Yamamoto A, Kurihara H, Doi T: Phosphorylation of nephrin triggers its internalization by raft-mediated endocytosis. J Am Soc Nephrol 2007, 20:2534-2545

29. Tossidou I, Teng B, Drobot L, Meyer-Schwesinger C, Worthmann K, Haller H, Schiffer M: CIN85/RukL is a novel binding partner of nephrin and podocin and mediates slit diaphragm turnover in podocytes. J Biol Chem 2010, 285:25285-25295

30. Asano T, Niimura F, Pastan I, Fogo AB, Ichikawa I, Matsusaka T: Permanent genetic tagging of podocytes: fate of injured podocytes in a mouse model of glomerular sclerosis. J Am Soc Nephrol 2005, 16: 2257-2262

31. Moeller MJ, Sanden SK, Soofi A, Wiggins RC, Holzman LB: Podocyte-specific expression of cre recombinase in transgenic mice. Genesis 2003, 35:39-42

32. Juhila J, Roozendaal R, Lassila M, Verbeek SJ, Holthofer H: Podocyte cell-specific expression of doxycycline inducible Cre recombinase in mice. J Am Soc Nephrol 2006, 17:648-654

33. Yokoi H, Kasahara M, Mukoyama M, Mori K, Kuwahara K, Fujikura J, Arai Y, Saito Y, Ogawa Y, Kuwabara T, Sugawara A, Nakao K: Podocyte-specific expression of tamoxifen-inducible Cre recombinase in mice. Nephrol Dial Transplant 2010, 25:2120-2124

34. Wang J, Wang Y, Long J, Chang BH, Wilson MH, Overbeek P, Danesh FR: Tamoxifen-inducible podocyte-specific iCre recombinase transgenic mouse provides a simple approach for modulation of podocytes in vivo. Genesis 2010, 48:446-451 